\title{
Low-carbon agriculture in South America to mitigate global climate change and advance food security
}

\author{
João Carlos de Moraes Sáa, ${ }^{\mathrm{a},}$, Rattan Lal ${ }^{\mathrm{b}}$, Carlos Clemente Cerri ${ }^{\mathrm{c}}$, Klaus Lorenz ${ }^{\mathrm{b}}$, \\ Mariangela Hungria ${ }^{\mathrm{d}}$, Paulo Cesar de Faccio Carvalho ${ }^{\mathrm{e}}$ \\ a Department of Soil Science and Agricultural Engineering, State University of Ponta Grossa, Av. Carlos Cavalcanti 4748, Campus de Uvaranas, 84030-900 Ponta Grossa, PR, Brazil \\ b School of Environment and Natural Resources and Carbon Management and Sequestration Center, The Ohio State University, 2021 Coffey Road, Columbus, OH 43210, USA \\ c State University of São Paulo, Centro de Energia Nuclear na Agricultura, Av. Centenário 303, 13416-970, Piracicaba, SP, Brazil \\ d Brazilian Agricultural Research Corporation - EMBRAPA Soybean, Rodovia Carlos João Strass, Distrito de Warta Caixa Postal: 231, 86001-970, Londrina, PR, Brazil \\ e Federal University of Rio Grande do Sul, Department of Forage Plants and Agrometeorology, Porto Alegre, 91540-000, RS, Brazil
}

\section{A R T I C L E I N F O}

\section{Article history:}

Received 5 July 2016

Received in revised form 3 October 2016

Accepted 19 October 2016

Available online 9 November 2016

\section{Keywords:}

Greenhouse gas

Best agricultural management practices

C-offset

Land use and land use change

\begin{abstract}
A B S T R A C T
The worldwide historical carbon (C) losses due to Land Use and Land-Use Change between 1870 and 2014 are estimated at $148 \mathrm{Pg} \mathrm{C}$ ( $1 \mathrm{Pg}=1$ billion ton). South America is chosen for this study because its soils contain $10.3 \%$ ( $160 \mathrm{Pg}$ C to $1-\mathrm{m}$ depth) of the soil organic carbon stock of the world soils, it is home to $5.7 \%$ ( 0.419 billion people) of the world population, and accounts for $8.6 \%$ of the world food (491 million tons) and $21.0 \%$ of meat production ( 355 million tons of cattle and buffalo). The annual $\mathrm{C}$ emissions from fossil fuel combustion and cement production in South America represent only 2.5\% ( $0.25 \mathrm{Pg} \mathrm{C}$ ) of the total global emissions ( $9.8 \mathrm{Pg} \mathrm{C})$. However, South America contributes $31.3 \%$ ( $0.34 \mathrm{Pg}$ C) of global annual greenhouse gas emissions (1.1 Pg C) through Land Use and Land Use Change. The potential of South America as a terrestrial C sink for mitigating climate change with adoption of Low-Carbon Agriculture (LCA) strategies based on scenario analysis method is $8.24 \mathrm{Pg}$ C between 2016 and 2050. The annual C offset for 2016 to 2020, 2021 to 2035, and 2036 to 2050 is estimated at $0.08,0.25$, and $0.28 \mathrm{Pg} \mathrm{C}$, respectively, equivalent to offsetting $7.5,22.2$ and $25.2 \%$ of the global annual greenhouse gas emissions by Land Use and Land Use Change for each period. Emission offset for LCA activities is estimated at $31.0 \%$ by restoration of degraded pasturelands, $25.6 \%$ by integrated crop-livestock-forestry-systems, $24.3 \%$ by no-till cropping systems, $12.8 \%$ by planted commercial forest and forestation, $4.2 \%$ by biological $\mathrm{N}$ fixation and $2.0 \%$ by recycling the industrial organic wastes. The ecosystem carbon payback time for historical $C$ losses from South America through LCA strategies may be 56 to 188 years, and the adoption of LCA can also increase food and meat production by 615 Mton or 17.6 Mton year $^{-1}$ and 56 Mton or 1.6 Mton year $^{-1}$, respectively, between 2016 and 2050.
\end{abstract}

(c) 2016 Elsevier Ltd. All rights reserved.

\section{Introduction}

The global $\mathrm{C}$ budget has been drastically altered by anthropogenic activities leading to perturbations in the atmospheric composition especially since the onset of the industrial era (Lal 2004; Lal, 2014; Houghton 2014; Le Quéré et al., 2014 and 2015). The components comprising the annual global C budget include five main sources and sinks (Lal 2004; Houghton 2014; Le Quéré et al., 2014 and 2015: i) $\mathrm{CO}_{2}$ emissions from fossil fuel combustion and cement production that represents $9.8 \pm$

Abbreviations: SOC, soil organic carbon; LU, Land Use; LUC, Land Use change; GHG, Greenhouse gas; LCA, Low Carbon-Agriculture; Pg, billion ton; RDPLi, restoring degraded pasture and livestock intensification; ICLFS, integrated crop-livestock-forest-system; NTcs, no-till cropping system; PCFF, planted commercial forest and forestation; BNF, biological $\mathrm{N}$ fixation; IAW, industrial animal waste.

* Corresponding author.

E-mail address: jcmsa@uepg.br (J.C.M. Sá).
0.5 Pg C year ${ }^{-1}$; ii) $\mathrm{CO}_{2}$ emissions from Land Use (LU) and Land Use Change (LUC) contributing $1.1 \pm 0.5 \mathrm{Pg} \mathrm{C}_{\text {year }}{ }^{-1}$; iii) atmospheric uptake by $3.9 \pm 0.2$ Pg C year $^{-1}$; iv) uptake by land-based sinks, with a mitigation capacity of $4.1 \pm 0.9 \operatorname{Pg~C}$ year $^{-1}$, and v) absorption by oceanic sink of $2.9 \pm 0.5 \mathrm{Pg} \mathrm{C}$ year $^{-1}$ (Houghton, 2014; Le Quéré et al., 2015). Global estimates of historical $C$ losses by LU and LUC range from 45 to $114 \mathrm{Pg} \mathrm{C}$ (mean $=79.5 \mathrm{Pg} \mathrm{C}$ ) for the pre- 1870 period, and from 108 to $188 \mathrm{Pg} \mathrm{C}$ (mean = $148 \mathrm{Pg} \mathrm{C}$ ) from 1870 to 2014 (Lal, 2004). Estimates of the depletion of $C$ stock from world soils are at 78 $\mathrm{Pg} C$ by cultivation (Lal, 2004) representing $5.0 \%$ of the total SOC stored currently in the world soils (to 1-m depth). However, the historical greenhouse gases (GHG) emissions with strong impacts on atmospheric composition include deforestation and burning of native vegetation (67 Pg C) representing 10.8\% of the C stock (Lal, 2004; Le Quéré et al., 2014 and 2015) in the terrestrial vegetation ( $620 \mathrm{Pg} \mathrm{C})$. The onset of land degradation in South America, triggered by the conversion of native 
vegetation to pastureland, has been aggravated by overgrazing and abandoning of the degraded pastures. The historical $\mathrm{C}$ losses comprised of: a) the vegetation $C$ emitted into the atmosphere by burning of the native vegetation (conversion to agricultural land) that was estimated at 7.3 $\mathrm{Pg} \mathrm{C}$ and by oxidation of SOC by ploughing equivalent to $8.1 \mathrm{Pg}$ C (Gloor et al., 2012), while a part of the vegetation-C released is recycled and returned to the global C cycle through land sink and oceanic sink (Houghton, 2014; Le Quéré et al., 2014 and 2015); and b) the fossil C emitted into the atmosphere by combustion of oil, coal and natural gas that creates a hiatus between the global $\mathrm{C}$ cycling and geologic $\mathrm{C}$ reservoir. South America is a low emitter of GHG from fossil fuel combustion contributing rather small historic emissions of $0.25 \mathrm{Pg} \mathrm{C}_{\mathrm{Cear}}{ }^{-1}$ (Gloor et al., 2012). However, the emissions by LU and LUC, especially by deforestation mainly from Amazon and Cerrado biomes contributes 0.34 Pg C year $^{-1}$ (Gloor et al., 2012), and had high impacts on increasing atmospheric concentrations of $\mathrm{CO}_{2}$ (Gebara and Thuault, 2010; Gouvello et al., 2010; Soares-Filho et al., 2012; Magalhães et al., 2014; Groppo et al., 2015). Brazil has implemented several key domestic and international initiatives to reduce GHG emissions and adopted policies to reduce emissions from deforestation in the Amazon forest by reducing the rate of deforestation by 60\% between 2004 and 2014 that represented $20 \%$ less emission by global LUC (Gebara and Thuault, 2010; Gouvello et al., 2010; Groppo et al., 2015).

The potential of agricultural best management practices towards offsetting GHG emissions is estimated at 0.3 to $1.17 \mathrm{Pg} \mathrm{C}$ year $^{-1}$ (Lam et al., 2013; Neufeldt et al., 2013; Neufeldt et al., 2015) and represents 2.7 to $10.4 \%$ of the global GHG emissions (Lal, 2004; Houghton, 2014; Le Quéré et al., 2014 and 2015). Among these agricultural practices, the C sink capacity of no-till (NT) and associated cropping systems to offset emissions and mitigate climate change has generated intense debate (Powlson et al., 2014; Sommer and Bossio, 2014; Corbeels et al., 2016; Powlson et al., 2016; VandenBygaart, 2016). The debatable issues include the effectiveness of NT to mitigate emissions (Neufeldt et al., 2013; Powlson et al., 2014; Sommer and Bossio, 2014), and the feasibility of adopting agricultural best management practices and upscaling to regional scale (Sá et al., 2013; Corbeels et al., 2016; Powlson et al., 2016). The contribution of NT management to mitigate climate change by $\mathrm{C}$ sequestration is perceived to be low presumably because: i) the capacity for soil C sink is finite (Sommer and Bossio, 2014; Adenle et al., 2015; Corbeels et al., 2016; Powlson et al., 2016;), ii) diverse crop sequences or combinations with worldwide adoption of NT promote variable effects of NT on crop yields at global scale (Pittelkow et al., 2014); iii) difficulty of obtaining credible estimates of SOC on landscape scale and requiring a complex framework encompassing a wide range of climate, soils (texture, mineralogy), crops and cropping systems which exacerbate uncertainties in assessing C sequestration (Sá, et al., 2013; Sommer and Bossio, 2014; Adenle et al., 2015; Lam et al., 2013); iv) high risks of re-emission of SOC sequestered because even a single tillage event in a long-term NT soil may negate previous gains in SOC stock (Sá et al., 2014); v) a high variation and uncertainties of the C sequestration rates in fields under NT involving three conservation agriculture principles (FAO, 2014; Kassam et al., 2015) already practiced on $<15 \%$ of the global cropland; and vi) low amount of the input of biomass- $\mathrm{C}$ return because of extreme weather events (e.g., long dry period or excessive rainfall).

Soil C sequestration rates under NT in Brazil selected were based on the three principles that encompass conservation agriculture (e.g., minimum soil disturbance - restricted to the sowing line, permanent soil cover by crop residues or live mulches and crop rotation and intercropping) reported by FAO (2014). Rates of C sequestration for tropical regions range from 0.83 to 1.61 and 1.37 to $2.05 \mathrm{Mg} \mathrm{C}^{-1-}$ year $^{-1}$ for $0-40 \mathrm{~cm}$ and $0-100 \mathrm{~cm}$ depths for (Sá et al., 2006; Blanchart et al., 2007; Sá et al., 2015; Corbeels et al., 2016; Miranda et al., 2016). These rates for subtropical regions range from 0.91 to 1.61 and 0.52 to $1.95 \mathrm{Mg} \mathrm{C}^{-1}$ year $^{-1}$ for $0-40$ and $0-100 \mathrm{~cm}$ layers, respectively (Diekow et al., 2005; Bayer et al., 2006; Sá et al., 2014). In
Argentina, rates of soil $C$ sequestration range from 0.40 to $1.55 \mathrm{Mg} \mathrm{C}$ ha $^{-1}$ year $^{-1}$ (Díaz-Zorita et al., 2002; Alvarez, 2005; Hernanz, et al., 2009; Alvarez et al., 2014). The present study is based on the hypothesis of overlapping and synergistic effects among LCA activities which could accentuate environmental quality, improve agronomic productivity, and minimize global climate change. The strategy is to develop an approach that encompasses protection and improved management of natural resources through adoption of agricultural best management practices for improving production efficiency. It is this approach that is termed as "Low-Carbon Agriculture (LCA) to mitigate GHG emissions (Gouvello et al., 2010; Soares-Filho et al., 2012; Gebara and Thuault, 2010; Magalhães et al., 2014). Thus, LCA is based on three principles: i) low carbon dioxide $\left(\mathrm{CO}_{2}\right)$ emissions from $\mathrm{LU}$ and LUC in response to Agricultural best management practices; ii) high $\mathrm{CO}_{2}$ mitigation through agricultural production systems based on agricultural best management practices; and iii) high $\mathrm{C}$ sequestration potential with the adoption of integrated crop-livestock-forestry-systems. The LCA strategy was launched by the Brazilian government as a national program in 2010 to promote specific agricultural activities based on agricultural best management practices which involved six major themes (Gouvello et al., 2010; Soares-Filho et al., 2012; Magalhães et al., 2014): i) restoration of degraded pastureland and promoting livestock intensification based on carrying capacity (RDPLi), ii) expansion of the area under NT and the associated cropping systems with high and diverse biomass-C inputs (NTcs), iii) adoption of integrated crop-livestock-forestry-systems (ICLFS), iv) promotion of biological $\mathrm{N}$ fixation (BNF), v) establishment of plantations of commercial forests and forestation (PCFF), and vi) application and recycling of industrial and animal wastes (IAW). Maintaining productivity gains at high levels necessitates adoption of agricultural systems with efficient management of the natural resources (Gouvello et al., 2010; Soares-Filho et al., 2012; Kang, 2013; Magalhães et al., 2014). Further, enhanced use efficiency of external inputs (e.g., seeds, fertilizers, agro-chemicals, machinery and equipment) that can contribute to enhance food security. The concept of food security was established by the United Nation's Universal Declaration of Human Rights in 1948. Article 25, states that: everyone has the right to a standard of living adequate for the health and well-being of himself and of his family, including food (U. Nations, 2014, http://www.un.org/es/documents/udhr/). The situation of hunger in Latin America still affects over 34 million people, which requires greater efforts to achieve hunger eradication during the current generation situation (FAO, 2015). Positive productive performance coupled with a diversity of policies that guarantee access for the most vulnerable, have helped to strengthen food and nutrition security and enabled the region to become a major global food supplier. Thus, an important discussion raises the following question: what is the potential of LCA strategies to mitigate climate change and advance food security in South America? This article is aimed at addressing this question.

\section{Material and methods}

In this study we used a method based on scenario analysis that means a process of analyzing possible future events by considering alternative possible outcomes, sometimes called "alternative worlds" (Duinker and Greig, 2007). Quantitative trend extrapolation simply projecting past data into the future based on the assumption that certain phenomena are likely to persist. This means enable variation and uncertainty to be quantified, mainly by using distributions instead of fixed values in risk assessment.

\subsection{Agricultural best management practices and low-carbon agriculture rationale}

Tilman et al. (2002) defined sustainable agriculture as agricultural best management practices that meet current and future societal needs for food and fiber, for ecosystem services, and for healthy lives, 
and that do so by maximizing the net benefit to society when all costs and benefits of the practices are considered. Therefore, in this study also, the term LCA refers to the adoption of agricultural practices characterized by low direct GHGs emissions, high storage of $\mathrm{C}$ in vegetation and soil, and strong mitigation of $\mathrm{CO}_{2}$ emissions. It is a type of agriculture based on low or an efficient use of external energy inputs and may involve some of the followings: i) reduced or no soil ploughing to decrease fossil fuels input, ii) increased crop diversity and cover crops to strengthen nutrient cycling and nutrient use efficiency, iii) increased biological N fixation by legumes (Robertson and Grace, 2004; Hungria et al., 2006) to decrease industrial mineral fertilizer $\mathrm{N}$ input (contribution based on ${ }^{15} \mathrm{~N}$ or $\mathrm{N}$-ureides technique is circa of $80 \%$ of total $\mathrm{N}$ uptake by plant and 20\% comes from soil, Hungria et al., 2006 and Hungria et al., 2006), iv) reduced $\mathrm{CO}_{2}$ emissions due to diverse production systems by combination of crop, livestock, and tree biomass production - integrated systems (Carvalho and Batello, 2009; Allen et al., 2010; Moraes et al., 2014), v) decreased pollutant emissions through crop rotation based on crop diversity and biomass input to decrease agrochemicals inputs to control weeds, diseases and pests, and vi) increased profit margin of the farming system. The goal of the LCA approach is to develop a broad-based constituency of stakeholders including public and private, academic and civil society, and to promote the philosophy that soil is a vital but finite resource and, therefore, must be used, improved and restored. The six themes of LCA activities in this study comprise of: 1) restoring degraded pastureland to promote livestock intensification (RDPLi) envisaging the recovery of soil functionality based on three strategies: a) enhancing soil fertility through acidity correction (management of liming and gypsum use) and efficient use of NPK fertilizers. The coefficient of $\mathrm{CO}_{2} \mathrm{Eq}$ emissions from lime use for each hectare is $0.24 \mathrm{Mg} \mathrm{CE}$ and discounted from the offsets obtained by restoration of degraded pastureland and livestock intensification; b) introducing forage species with high quality and potential of biomass production; c) promoting livestock intensification based on forage management to increase carrying capacity; 2) Increasing land area under NT and the associated cropping systems (NTcs), based on the three CA principles: a) minimizing soil disturbance that is limited to planting row; b) establishing permanent soil cover with crop residues and live mulches; and c) enhancing bio diversification of plant species regarding crop rotation and intercropping with high biomass-C input; 3 ) adopting Integrated Crop-Livestock-Forestry-Systems (ICLFS) to promote synergistic effects among the components. It consists of growing forest species simultaneously with commercial crops (e.g., soybeans, maize, or beans) added during the first 2 or 3 years. After crop harvest, the area is planted to forage for livestock, associated with maize (Zea mays) or sorghum (Sorghum bicolor). By the time grains are harvested, the pasture is already established between the tree rows, enabling grazing, until the timber is harvested; 4) promoting biological N fixation (BNF), through bio catalytic conversion of atmospheric $\mathrm{N}_{2}$ to ammonium. In agricultural production systems, the most important contribution occurs with the symbiosis of dinitrogen-fixing bacteria and plants, such as soybean and majority of other legumes; 5) establishing plantations of commercial forests and forestation (PCFF), within the land area of cultivated forests with species characterized by fast growth and wood use for construction, furniture, and for recreation, and 6) treating and recycling industrial and animal wastes (IAW) resulting from animal production for generation of energy and for composting envisaged to replace or fortify the mineral fertilizer.

\subsection{Criteria adopted to expanding land under LCA}

Estimates for mitigation potential in this study cover a total of 35 years, divided into three periods. The criteria used to define each period were based on the following: (i) the 2016 to 2020 period was based on premises of LCA program launched by the Brazilian government in 2010 (Gouvello, et al., 2010; Brazilian Low-Carbon Agriculture Program, 2012) that defined goals for what agriculture would be used to attain the main targets proposed at COP 15 . The projections until 2020 (Table 1) were used as base line for this period; (ii) the 2021 to 2035 period was based on the estimate of land expansion using national surveys, Landsat cover and inventories to adjust a linear and polynomial regressions to obtain the angular coefficient to estimate the land expansion and the uncertainties for each coefficient; (iii) the 2036 to 2050 period followed the methodology applied to 2021 to 2035 but adding a reduction factor to adjust the coefficients because the increases are not linear or indefinably crescent.

The pattern to establish the land expansion for each LCA activity is based on four principles: i) choosing the basic target defined by LCA program launched by the Brazilian Government (Gouvello et al., 2010; Brazilian LCA program, 2012; Magalhães et al., 2014), and predicting strategies to be achieved for the period 2016 to 2020 as adjusted for the countries mentioned in Table 1; ii) using national surveys with historic series of evolution of cropland (http://www.conab.gov.br/ conteudos.php?a=1252\&), livestock, forestry cover, and data about industrial waste processing, iii) using Landsat information for land use surface evolution (Gusso, et al., 2012), and iv) using linear regression of the historic series to calculate growth rates for integrated crop-livestock-forestry-systems, NT cropping systems, biological N fixation and plantations of commercial forest and forestation. The data about expansion of land for each LCA activity are obtained from national surveys and FAOSTAT (FAO, assessed in June and December of 2015).

The column entitled "current land" use shown in Table 1 represents the status of LCA activities updated to December 2015 according to surveys (Gouvello et al., 2010; Brazilian LCA program, 2012), and was used to calculate the historical C-offset until 2015 (Food and Agriculture, 2016).

The value for restoration of degraded pastureland and livestock intensification was based on the assertion of LCA Brazilian program for the period from 2016 to 2020, and combined with projection for Argentina (land area under NT management, assessed in June 2015), Chile and other South America countries (FAOSTAT assessed in November 2015). The integrated crop-livestock-forestry-systems, plantations of commercial forest and forestation, biological $\mathrm{N}$ fixation and industrial and animal wastes values for the period 2016 to 2020 were obtained from LCA Brazilian program (see Table 1), adjusted with prediction for Argentina and Chile and estimated for other South America countries (Uruguay, Peru, Colombia, Bolivia).

The coefficients listed in Table 1 (Annual land expansion/country) refer to the angular coefficients obtained from regression analysis using National survey database for each LCA activity. For example: the NT cropping system area expansion for 2021 to 2035 period was calculated from the equation: NT expansion area (Mha) $=1.64$ year -2.18 , $\mathrm{R}^{2}=0.97$; and for 2036 to 2050 by NT expansion area (Mha) $=$ 1.23 year $+17.8, \mathrm{R}^{2}=0.98$.

The values in the current land area were added to the expanded area for the period from 2021 to 2035 and 2036 to 2050 for all LCA activities based on the sum of current land + total land expansion for the entire period (2016 to 2050). For example, the estimation of land expansion for restoration of degraded pastureland and livestock intensification from 2016 to 2050 period was: Land expansion $=10$ Mha (refers the current land until 2015) + 20 Mha (expansion land for 2016 to $2020)+35$ Mha (expansion land for 2021 to 2035) + 39 Mha (expansion land for 2036 to 2050 ) $=104$ Mha. The other LCA components were estimated following the same procedure.

\subsection{Rationale for deducing LCA coefficients}

The coefficients for estimating the C-offset were based on four principles: i) refereed articles identified in Web of Science, ii) national surveys and historical series emphasizing the growth rate of each activity, iii) the Brazilian target for LCA program launched in 2010 and adjusted for the period from 2016 to 2020 (Table 2) and Brazilian participation on COP-21, and iv) weighted average and linear regression applied to 
Table 1

Annual and total land expansion area in million ha (Mha) projected for each Low-Carbon Agriculture (LCA) activity corresponding with each scenario period.

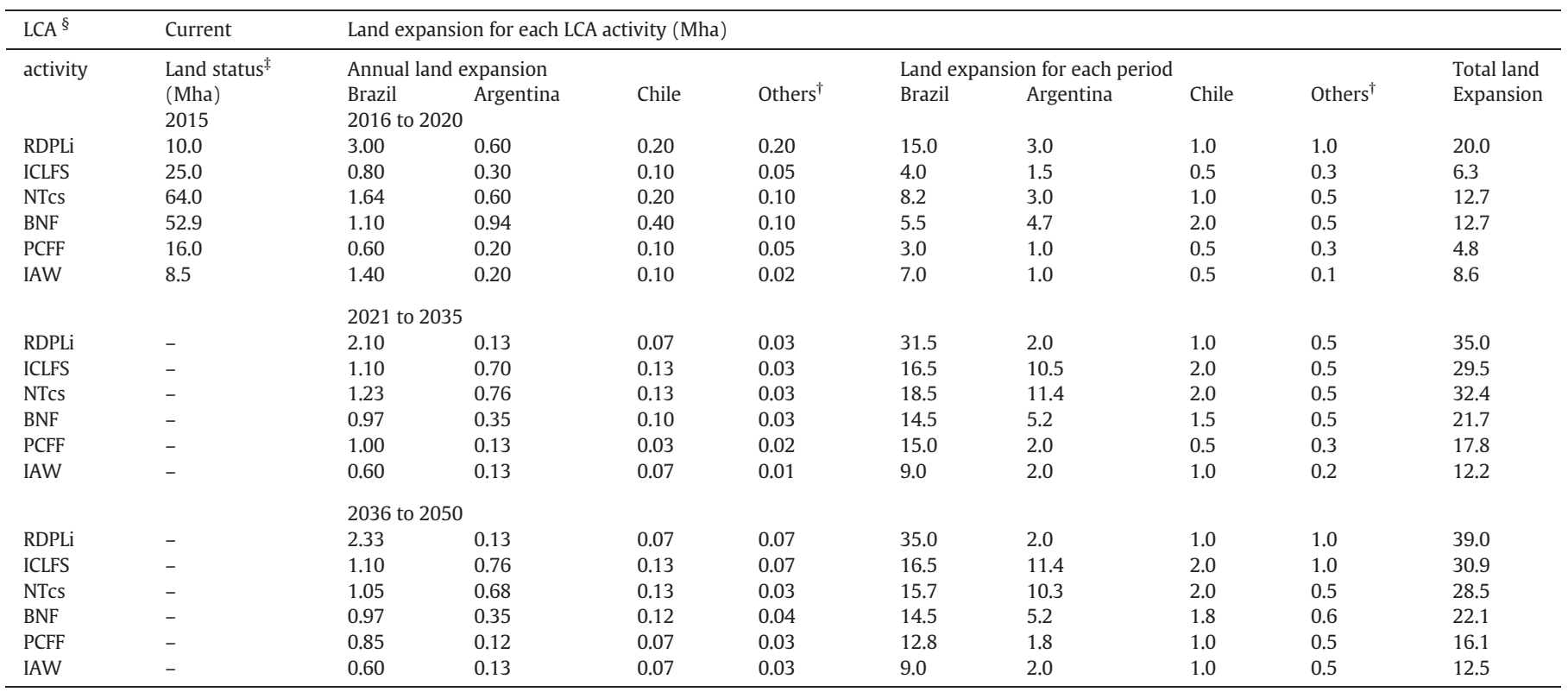

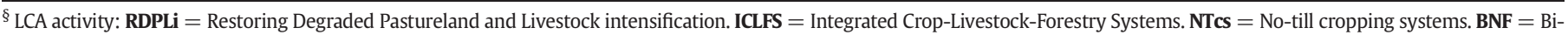

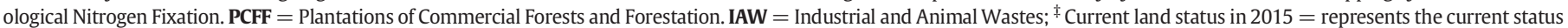

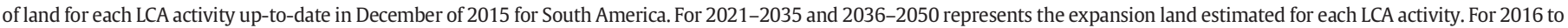
2050 represents the sum of the three periods for each LCA activity; ${ }^{\dagger}$ Refers the all other countries of South America.

the data series to estimate the growth rate for expansion of cropland and prediction of food production (Tilman and Clark, 2014). The restoration of degraded pastureland and livestock intensification coefficient for the periods from 2021 to 2035 and 2036 to 2050 (Zhu et al., 2016) were obtained considering a rate of decline (Gibbs and Salmon, 2015) in land restoration of $0.8 \%$ (e.g., $12 \%$ for the whole period) and 0.73 (e.g., $11 \%$ for the whole period), respectively. The integrated crop-livestock-forestry-systems (Carvalho and Batello, 2009; Allen et al., 2010; Moraes et al., 2014; Gil et al., 2015) and NT cropping systems for 2016 to 2020 were based on the average rate of SOC sequestration obtained from refereed journal articles involving the three components of NT (low soil disturbance, continuous ground cover, and diversified crop rotation (The three principles of conservation agriculture, 2014)) (Derpersch et al., 2014; FAO, 2014; Tilman and Clark, 2014). The articles which did not follow these criteria were excluded. In addition, those articles were selected which also reported SOC stock measurements to 1$m$ depth. The coefficients for the calculation of NT expansion area were

Table 2

Coefficients to estimate C-offsets for each Low-Carbon Agriculture (LCA) activities in South America.

\begin{tabular}{lllll}
\hline LCA & Current land & \multicolumn{3}{l}{ Coefficients of LCA for each period } \\
\hline activity $^{\S}$ & $\begin{array}{l}\text { (until 2015) } \\
\text { ton } \text { ha }^{-1} \text { year }^{-1}\end{array}$ & 2016-2020 & $2021-2035$ & $2036-2050$ \\
RDPLi & $1.2 \pm 0.21$ & $1.70 \pm 0.32$ & $2.04 \pm 0.27$ & $2.24 \pm 0.21$ \\
ICLFS & $1.4 \pm 0.25$ & $1.80 \pm 0.41$ & $2.16 \pm 0.30$ & $2.38 \pm 0.26$ \\
NTCS & $0.6 \pm 0.13$ & $1.61 \pm 0.22$ & $1.93 \pm 0.19$ & $2.26 \pm 0.20$ \\
BNF & $0.4 \pm 0.09$ & $0.48 \pm 0.01$ & $0.48 \pm 0.01$ & $0.48 \pm 0.01$ \\
PCFF & $1.4 \pm 0.19$ & $1.45 \pm 0.10$ & $1.81 \pm 0.14$ & $2.26 \pm 0.19$ \\
IAW & $0.2 \pm 0.06$ & $0.40 \pm 0.08$ & $0.40 \pm 0.08$ & $0.40 \pm 0.08$
\end{tabular}

$\S$ LCA activity: $\mathbf{R D P L i}=$ Restoration of Degraded Pastureland and Livestock intensification; ICLFS = Integrated Crop-Livestock-Forestry Systems; NTcs = No-till cropping systems; $\mathbf{B N F}=$ Biological Nitrogen Fixation; $\mathbf{P C F F}=$ Planted Commercial Forests and Forestation IAW $=$ Industrial and Animal Wastes. ${ }^{\ddagger}$ coefficients for each LCA activity until 2015 represents the current status of land for each LCA activity up-to-date in December of 2015 obtained from linear regressions from the historical data for Brazil and Argentina. The coefficient of expansion was 1.64 year $^{-1}$ for the 2016 to $2020,1.23$ year $^{-1}$ for 2021 to 2035 , and 1.05 year $^{-1}$ for 2036 to 2050 period (Brazilian National grain production survey, 2015; Brazilian National Federation of No-tillage, 2015; AAPRESID, Argentina, 2015). The estimated surface areas for different periods are shown in Table 1.

The biological $\mathrm{N}$ fixation coefficient was obtained based on the approach that the efficiency of Fertilizer-N applied in tropical and subtropical regions is $50 \%$ less than that for each $\mathrm{kg}$ of $\mathrm{N}$ synthesized by soybean via biological N fixation (Robertson and Grace, 2004; Hungria et al., 2006; Ormeño-Orrillo et al., 2013). The calculation procedure involves the following steps: i) The mean soybean (Glycine max) yield for the 2014-2015 growing season for Brazil (3.01 $\mathrm{Mg} \mathrm{ha}^{-1}$ ) and Argentina (3.30 $\mathrm{Mg} \mathrm{ha}^{-1}$ ) was $3.16 \mathrm{Mg} \mathrm{ha}^{-1}$, and these two countries accounted for $\sim 90 \%$ of all soybean grains produced in South America; ii) the amount of $\mathrm{N}$ absorbed by $1 \mathrm{Mg}$ of soybean grain is $80 \mathrm{~kg}$, and the total amount of $\mathrm{N}$ absorbed per hectare (based on the average for soybean in Brazil) was $252 \mathrm{~kg} \mathrm{~N} \mathrm{ha}^{-1}$; iii) the contribution of biological $\mathrm{N}$ fixation (BNF) per each $\mathrm{Mg}$ of soybean grain was 79 to $84 \%$ (Hungria et al., 2006), and the average was $81.5 \%$ and equivalent to 0.815 ; iv) $1 \mathrm{~kg}$ of $\mathrm{N}$ derived from biological $\mathrm{N}$ fixation was equivalent to $2 \mathrm{~kg}$ of Fertilizer- $\mathrm{N}$, based on the efficiency concept of $\mathrm{N}$ use; and v) the GHG emission caused by each $\mathrm{kg}$ of Fertilizer- $\mathrm{N}$ is equivalent to $4.5 \mathrm{~kg} \mathrm{CO}_{2}-\mathrm{C}_{\mathrm{eq}}$ (Hungria et al., 2006). Thus, the coefficient of BNF to estimate C-offset contribution per ha ${ }^{-1}$ was calculated as follow:

$$
\begin{aligned}
& \text { Contribution of BNF per ha }{ }^{-1}: 252 \mathrm{~kg} \mathrm{~N} \mathrm{ha}^{-1} \times 0.815 \\
& =205 \mathrm{~kg} \mathrm{~N} \mathrm{ha}^{-1}
\end{aligned}
$$

Where: $252 \mathrm{~kg} \mathrm{~N} \mathrm{ha}^{-1}$ is the total amount of $\mathrm{N}$ absorbed from $3016 \mathrm{~kg} \mathrm{~N} \mathrm{ha}^{-1}$ and 0.815 is the percentage of the BNF contribution;

Equivalence between BNF-N and Fertilizer $-\mathrm{N}$

$$
=205 \mathrm{~kg} \mathrm{~N} \mathrm{ha}^{-1} \times 2=410 \mathrm{~kg} \mathrm{~N} \mathrm{ha}^{-1}
$$


Where:205 $\mathrm{kg} \mathrm{N} \mathrm{ha}^{-1}$ represents the total amount of $\mathrm{N}$ derived from $\mathrm{BNF}$ and the factor 2 represents the Fertilizer-N efficiency (equivalent to $50 \%$ for each $\mathrm{kg}$ of $\mathrm{N}$ from BNF absorbed).

$$
\begin{aligned}
& \text { Equivalence to } \mathrm{CO}_{2}-\mathrm{C}_{\mathrm{eq}}=410 \mathrm{~kg} \mathrm{~N} \mathrm{ha}^{-1} \times 4.5 \mathrm{CO}_{2}-\mathrm{C} \mathrm{kg}^{-1} \mathrm{~N} \\
& \quad=1845 \mathrm{~kg} \mathrm{CO}_{2}-\mathrm{C} \mathrm{ha}^{-1}
\end{aligned}
$$

Where: $410 \mathrm{~kg} \mathrm{~N}^{-1}$ is the equivalence between the BNF-N and Fertilizer- $\mathrm{N}$, and 4.5 is the coefficient that represents the equivalent emissions for $1 \mathrm{~kg}$ of Fertilizer-N. Thus, the annual mitigation potential for each ha of soybean was $1.845 \mathrm{Mg} \mathrm{CO}_{2}-\mathrm{C}_{\mathrm{eq}}$ or $0.504 \mathrm{Mg} \mathrm{C}^{-1}$ year $^{-1}$. The BNF balance was discounted at the start of the $\mathrm{N}$ application used in the fertilizer formula (i.e., $8 \mathrm{~kg} \mathrm{~N} \mathrm{ha}^{-1}$ ). Thus, the emissions discounted were: $8 \mathrm{~kg} \mathrm{~N} \times 4.5 \mathrm{~kg} \mathrm{CO}_{2}-\mathrm{C}_{\mathrm{eq}}=36 \mathrm{~kg} \mathrm{CO}_{2}-\mathrm{C}_{\mathrm{eq}}$ ha ${ }^{-1}$ or 0.036 ton $\mathrm{CO}_{2}-\mathrm{C}_{\mathrm{eq}}$ ha $^{-1}$.

\subsection{Calculations of C-offset predictions}

The prediction of C-offset for all LCA activities was based on two calculations procedure as follow:

1) Estimation of C-offset for LCA surface area until December 2015.

C - offset $=\left(\right.$ Current land in $2015 \times$ Coefficient for each LCA activity in Mg ha ${ }^{-1}$ year $\left.^{-1}\right)$

Where:C-offset is the amount of $\mathrm{C}$ mitigated by each LCA activity in Current land refers to the land area until December 2015 under LCA; and coefficient for each LCA activity refers to the historical coefficients listed in Table 2. For example: $10 \mathrm{Mh}$ is the current land for restoring degraded pasture and livestock intensification area until 2015 (Table 1) that was included in the restoration process; and 1.2 is the coefficient (Table 2) used to calculate C-offset.

2) Estimation of C-offset for LCA activities for each project period in this study.

$$
\begin{aligned}
\mathrm{C}-\text { offset }= & \text { Total land expansion per period in Mha } \\
& \times \text { Coefficient for each LCA activity } \\
& \times \text { years for each period })
\end{aligned}
$$

For example, the C-offset for the period of 2016 to 2020 for restoration of degraded pastureland and livestock intensification (RDPLi) was estimated by:

C-offset $=\left(20 \mathrm{Mha} \times 1.70 \mathrm{Mg} \mathrm{C}^{-1}\right.$ year $^{-1} \times 5$ years $) / 1000$

C-offset $=0.170$ Pg CWhere:20 Mha is the land area estimated for restoration of degraded pastureland and livestock intensification for the 2016-2020 period, and $1.70 \mathrm{Mg} \mathrm{C} \mathrm{ha}^{-1}$ year $^{-1}$ is the annual rate of $\mathrm{C}$ mitigated by restoring degraded pasture and livestock intensification for 2016 to 2020 period (Table 2) and, divided per 1000 to transform millions of $\mathrm{Mg} \mathrm{C}$ into $\mathrm{Pg} \mathrm{C}$. The same procedure was used for all LCA activity coefficients and for each period

\subsection{Ecosystem carbon pay-back time rationale, calculations and estimation of food increase by LCA strategies}

The term ecosystem carbon pay-back time was reported by Gibbs et al. (2008) to designate the number of years needed to produce carbon savings from burning biofuels instead of, to compensate for carbon emissions incurred by clearing land to grow biofuel crops. In this study, the focus was on the relationship between clearing land for food crops and pastures on the concept of how large the agricultural systems carbon debts are, and how many years are required to repay them. It means that the losses by burning vegetation during the conversion to agricultural systems and the soil $\mathrm{C}$ oxidation through plough tillage to grow crops can be compensated by an agricultural system with capability to compensate these losses. The carbon debt was based on the report by Lal (2004) that accounted for the historical losses by soil of $78 \mathrm{Pg} \mathrm{C}$ and $67 \mathrm{Pg} \mathrm{C}$ by deforestation, and the losses by South America equivalent to $15.4 \mathrm{Pg} \mathrm{C} \mathrm{(} 7.3$ by soil losses and 8.1 by deforestation = burning the vegetation) reported by Gloor et al., (2012). The ecosystem C pay-back time (ECPT) was calculated referring to annual world and South America (SA) emissions by LU and LUC as follow:

1) World compensation:

$\mathrm{ECPT}=$ Annual $\mathrm{C}$ emissions by LU and LUC in the world/Annual C offset

by LCA of each period

Where:ECPT is ecosystem C pay-back time and refers to the number of years spent by LCA strategies to recover the amount of $C$ lost by deforestation and soil oxidation by plough tillage; annual C emissions by LU and LUC in the world refers to the emissions equivalent to $1.1 \mathrm{Pg} C$ reported by Le Quéré et al., (2014), and annual C offset by LCA refers to the amount of $\mathrm{C}$ mitigation by LCA strategies for each period estimated in this study.

2) South America (SA) compensation based on annual C emissions by SA and the historical losses by vegetation burning and soil oxidation that is equivalent to $15.4 \mathrm{Pg} \mathrm{C}$ (Gloor et al., 2012):

$\mathrm{ECPT}=$ Annual $\mathrm{C}$ emissions by LU and LUC in SA/Annual C offset by LCA of each period

Where:Annual C emissions by LU and LUC in SA is $0.34 \mathrm{Pg} C$ (Gloor et al., 2012), and annual $C$ offset by LCA of each period in SA refers to the $C$ mitigation by LCA strategies for each period and the entire period (2016 to 2050) estimated in this study.

$\mathrm{ECPT}=$ Historical C losses by vegetation burning and soil cultivation/C mitigation by LCA strategies for each and the entire period.

The estimations of food increase in response to LCA implementation was based on the following procedure: i) survey of average yield of the main crops involved in the production systems; ii) expanded land area for each LCA activity; and iii) net gain of LCA based on the difference between crop yield under conservation agriculture and plough tillage. Food production was obtained by multiplying yield $\mathrm{ha}^{-1}$ by the expansion area in Mha. Average yields for estimation was based on the National surveys and international reports (http://apps.fas.usda.gov/psdonline/circulars/production.pdf). We used the weighted average between Brazil and Argentina for soybean for 2015 (Soybean $=3.16 \mathrm{Mg} \mathrm{ha}^{-1}$; Maize $=5.42 \mathrm{Mg} \mathrm{ha}^{-1}$; Wheat $\left.=2.72 \mathrm{Mg} \mathrm{ha}^{-1}\right)$ (Agriculture Ministry of Brazil - Soybean and grain production, 2015). For example, the calculation of soybean increase food for restoration of degraded pastureland and livestock intensification (RDPLi) followed the procedure: increase soybean production in RDPLI $=3.16 \mathrm{Mg} \mathrm{ha}^{-1} \times 9.4 \mathrm{Mha}=29.7 \mathrm{M}$ MgWhere:3.16 $\mathrm{Mg} \mathrm{ha}^{-1}$ refers the average soybean yield for South America up-to-date for 2015, and 9.4 Mha refers the expansion area in million ha with soybean under restoring degraded pasture and livestock intensification in South America. 


\section{Results}

\subsection{Scenarios for carbon offsets with LCA}

The following scenarios are based on the global SOC stock to 1-m depth. Considering only the surface $0-30 \mathrm{~cm}$ layer (plough depth) is not sufficient because it does not include the large SOC stock in the sub-soil (Sá et al., 2013; Sommer and Bossio, 2014; Adenle et al., 2015). On the other hand, estimates of SOC stock to 2 or 3-m depth are not yet widely available.

Three scenarios are considered feasible to expand the protocol based on the voluntary mitigation goal proposed by Brazil in Copenhagen in 2009 (Gouvello et al., 2010; Magalhães et al., 2014). The large reduction in deforestation in the Amazon biome was proposed because it is the major source of $\mathrm{C}$ emissions. The proposal announced by Brazil was to reduce GHG emissions by $36.1-38.9 \%$ by 2020 through creation of a $\mathrm{Na}-$ tional Climate Change Policy Plan (Darela filho et al., 2016).

In the first scenario envisaging the period of 2016-2020, thereafter designated "Reference Scenario", the goal is to reduce global GHG emissions by $10 \%$ from LU and LUC with high intensification of three LCA activities: (i) restoration of degraded pastureland and livestock intensification, integrated crop-livestock-forestry system, and expansion of NT cropping systems. NT is widely practiced in South America, on 64 million hectare (Mha) that represents $41.3 \%$ of the 155 Mha global land area under NT (Lal, 2015). The strategy is to expand the adoption of NT on 12.7 Mha in SA (8.2 Mha in Brazil) along with diversification and intensification of the cropping systems based on the rationale of: "producing more with less", thereby reducing $\mathrm{CO}_{2}$ emissions, enhancing $\mathrm{C}$ sequestration, and making agriculture integral to any agenda to mitigating climate change (Lal, 2014; Magalhães et al., 2014). In this scenario, we included the Brazilian government proposal and from other South America countries comprising of 20 Mha of degraded pastureland to be restored, 6.3 Mha of land to be managed under integrated crop-livestock-forestry system, 5.5 Mha additional land to be used for growing oil crops (soybean) with the auxillary benefits of biological $\mathrm{N}$ fixation, and 7 Mha for using industrial and animal wastes. The implementation of the reference scenario can offset $7.5 \%$ of global emissions from LU and

Table 3

Contribution of each Low-Carbon Agriculture (LCA) activity to C-offsets (Pg C C $^{\mathrm{a}}$ for unti 2015 (current surface area), for each period and the entire study period (2016-2050).

\begin{tabular}{llllll}
\hline LCA & \multicolumn{4}{l}{ C-offset contribution of each LCA activity } & Total C-offset $^{\mathrm{d}}$ \\
\hline Activity $^{\mathrm{a}}$ & Until 2015 & $2016-2020$ & $2021-2035$ & $2036-2050$ & $2016-2050$ \\
& Pg C & & & & \\
RDPLi & 0.012 & 0.170 & 1.071 & 1.313 & 2.55 \\
ICLFS & 0.034 & 0.056 & 0.956 & 1.101 & 2.11 \\
NTcs & 0.039 & 0.102 & 0.939 & 0.966 & 2.01 \\
BNF & 0.024 & 0.030 & 0.156 & 0.159 & 0.35 \\
PCFF & 0.022 & 0.034 & 0.483 & 0.544 & 1.06 \\
IAW & 0.001 & 0.017 & 0.073 & 0.075 & 0.17 \\
Accumulated & 0.13 & 0.41 & 3.68 & 4.16 & 8.24 \\
& & & & & \\
RDPLi & - & 41.4 & 29.1 & 31.6 & 31.6 \\
ICLFS & - & 13.7 & 26.0 & 26.5 & 25.6 \\
NTCS & - & 24.9 & 25.5 & 23.2 & 24.3 \\
BNF & - & 7.4 & 4.2 & 3.8 & 4.2 \\
PCFF & - & 8.4 & 13.1 & 13.1 & 12.8 \\
IAW & - & 4.2 & 2.0 & 1.8 & 2.0 \\
\hline
\end{tabular}

a C-offset estimated for the current surface area until December 2015 (see Table 1) for each LCA activity.

b C-offset estimated for each LCA activity for 2016-2020, 2021-2035, 2036-2050.

c C-offset estimated for each LCA activity for the entire period (2016-2050).

d LCA activities: RDPLi = Restoration of Degraded Pastureland and Livestock intensification; ICLFS = Integrated Crop-Livestock-Forestry Systems; NTcs = No-till cropping systems; $\mathbf{B N F}=$ Biological Nitrogen Fixation; $\mathbf{P C F F}=$ Planted Commercial Forests and Forestation; IAW = Industrial and Animal Wastes.

e Weighted average for LCA strategies for each period and for the entire period (20162050). The reference value for the calculation is the sum of all C-offset by LCA activities $=8.24 \mathrm{Pg} \mathrm{C}$.
LUC. Agricultural management activities to achieve this target include restoration of degraded pastureland and livestock intensification of $41.4 \%$, NT cropping systems with contribution of $24.9 \%$, and integrated crop-livestock-forestry-systems of $13.7 \%$, and - these three activities achieve $80 \%$ of GHG mitigation from 2015 to 2020 (Table 3).

In the 2nd scenario covering the target period of 2021 to 2035, total area under agricultural use will be expanded to reduce GHG emissions from LU and LUC by 20\%. Most of the envisioned expansion is expected to occur through the restoration of degraded pastureland and livestock intensification, by increase of the carrying capacity on 35 Mha (2.3 Mha year ${ }^{-1}$ ), enhancement of integrated crop-livestock-forestry system on 29.5 Mha (1.96 Mha year $^{-1}$ ), plantations of commercial forests and forestation on 17.8 Mha (1.2 Mha year $^{-1}$ ), use of NT cropping systems on 32.4 Mha (2.16 Mha year ${ }^{-1}$ ), and the expansion of oil crops on 21.7 Mha (1.45 Mha year ${ }^{-1}$ ), especially soybean (Glycine max) which is expected to occupy most of these areas. This scenario involved the enhancement potential of integrated crop-livestock-forestry-systems, which is almost 10 times as long as the first one, and is based on the intensification of livestock production systems (Table 1). The implementation of the reference scenario can offset $22.3 \%$ of global emissions from LU and LUC.

The restoration process is accentuated by synergism between diversification, input of livestock waste (urine and feces), and increase in crop biomass through biological $\mathrm{N}$ fixation by including legumes in the rotation which can offset $24.5 \%$ of global LU and LUC emissions.

In the third scenario covering the target period of 2036 to 2050, the goal is to reduce GHG emissions from LU and LUC by $30 \%$. The strategy is to implement integrated crop-livestock-forestry-systems on 30.9 Mha (Table 1), consolidate NT cropping systems on $75 \%$ of arable land area, expand restoration of degraded livestock pastureland through restoration and intensification of pastureland, expand oil crop production in conjunction with biological N fixation to 22.1 Mha (Table 1) and increase biological $\mathrm{N}$ fixation in other legumes used for grain production and green manure, and recycle industrial and animal waste. The optimization of agricultural best management practices is highlighted by the enhancement of all agricultural activities to achieve the best performance. Thus, improved productivity can offset $25.2 \%$ of global LU and LUC emissions through integrated management of soil resources. Adoption of NT cropping systems stabilizes, and the lack of restoration of degraded pastureland and livestock intensification and integrated croplivestock-forestry-systems advances while achieving the mitigation goals.

\section{Discussion}

\subsection{Global carbon offset by adopting LCA}

During the first period, enhancing diversification of biomass- $\mathrm{C}$ input associated with NT cropping systems accentuates SOC buildup in depleted tropical lands as the driving force to increase the mitigation of GHG emissions. Increase in input of biomass- $C$ from 4.5 $\mathrm{MgC} \mathrm{ha}{ }^{-1}$ year $^{-1}$ to $6.0-8.0 \mathrm{Mg} \mathrm{C}^{-1}$ year $^{-1}$ by biodiversity enhancement makes NT cropping systems an important BMP's for restoring SOC stocks (Lal, 2010; Antle and Ogle, 2012; Kirkegaard et al., 2014; Carter et al., 2015; Castelhano et al., 2015; Corbeels et al., 2016). Any concerns about a limited potential of NT, can be addressed by adopting a system approach (Sommer and Bossio, 2014; Sá et al., 2015; Corbeels et al., 2016). Indeed, both technical and attainable potential of $C$ sequestration by NT can be enhanced by synergistic action among the components of conservation agriculture and improvement of agricultural best management practices through strategic combination of quantity, quality and frequency of biomass-C additions (Diekow et al., 2005; Blanchart et al., 2007; Sá et al., 2015). NT will be a strong option for SOC sequestration when practiced with due consideration of the conceptual components for conservation agriculture. Instead, SOC sequestration by NT without 
all components is almost nil or negligible (Boddey et al., 2010; Lal, 2015; Sá et al., 2015). SOC sequestration is triggered by the positive balance between $\mathrm{C}$ gains by input of crop residues and $\mathrm{C}$ losses by microbial oxidation, soil erosion and leaching. Nevertheless, the contribution of NT cropping systems is finite, and is determined by the time taken to attain $C$ saturation. The latter can vary from 50 to 87 years (Sommer and Bossio, 2014). The LCA activities involve contributions to restoration of degraded pastureland and livestock intensification by $41.4 \%$, followed by NT cropping systems (24.9\%), integrated crop-livestock-forestry-systems (16.1\%), and accounting for $80 \%$ of the estimated C sink capacity of $0.41 \mathrm{Pg} \mathrm{C}$ or $0.08 \mathrm{Pg} \mathrm{C}$ year $^{-1}$ for the $2016-2020$ period (Fig. 1 ). Soil productivity can be doubled or even tripled in response by: increasing input of biomass- $C$ by growing cover crops, neutralizing soil acidity, enhancing soil fertility, and restoring degraded pasturelands by increasing the animal units per ha from 2.5 to 3.0 which can double or even triple agronomic productivity (Hobbs et al., 2008; Lal, 2010; Tilman and Clark, 2014).

For the second period, the mitigation potential is increased to $22.3 \%$ (Table 3 ) of the LU and LUC emissions driven by restoration of degraded pastureland and livestock intensification (29.1\%), integrated crop-livestock-forestry-systems (26.0\%), and NT cropping systems (25.5\%) achieving $80.6 \%$ of the sink capacity.

During the third period, the principal strategy is to: promote adoption of agricultural best management practices, integrate processes of soil C cycling, restore soil resilience, advance sustainable agriculture that enhance the mitigation potential to $25.5 \%$ of the world LU emissions. Overall the restoration of degraded pastureland and livestock intensification have a potential to mitigate GHGs by $31.6 \%$ compared with that of $26.5 \%$ for integrated crop-livestock-forestry-systems and $23.2 \%$ for NT cropping systems. However, increase in NT cropping systems can be up to $49.7 \%$ (weighted average) when it is associated with integrated crop-livestock-forestry-systems, because NT is a basic soil management in all operation of integrated crop-livestock-forestry-systems.
Thus, the total $\mathrm{C}$ offset including all three scenarios is predicted to be $8.38 \mathrm{Pg}$ C over 35 year period from 2015 to 2050 (Fig. 1). Although NT cropping systems has an important impact on mitigating GHG emissions (Table 3, weighted average \% for entire period $=24.4 \%$ ), other components of the Agricultural best management practices interacting in synergism with NT could have even higher mitigational impact. The basic strategy of LCA is to promote a systemic approach of reducing fluxes of GHG from soil while meeting the needs of growing population by enhancing the productive capacity of soil resources and advancing food and nutritional security. Thus, improving the environment and offsetting anthropogenic emissions can also increase food production. Implementation of LCA between 2016 and 2050 in South America can increase food production (Table 4) by $615 \mathrm{M} \mathrm{Mg}$ of grains (by $39.6 \%$ for soybean and $61.4 \%$ for cereals), and $55.5 \mathrm{M} \mathrm{Mg}$ of meat (cattle)

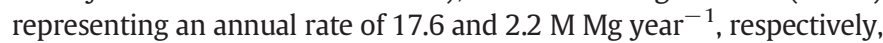
or $\sim 10 \%$ increase in the world food production. It is also justified to conclude that the adoption of LCA after the third period of South America can offset $0.28 \mathrm{Pg} \mathrm{C}$ (Fig. 1), which is equivalent to negating $25.5 \%$ of global LU and LUC emissions (Fig. 1). These projections are also in accord with the recent findings for the tropics (Carter, et al., 2015).

Most impacts of LCA activity have been attributed to Brazil's contribution of 65.7, 70.7 and $69.8 \%$ to the C-offset for 2016-2020, 2021-2035 and 2036-2050, respectively. Similar offset for Argentina are estimated at $21.8 \%, 22 \%$ and $21.0 \%$, respectively. Brazil is geographically the largest country in South America occupying $48 \%$ of the total land area of $17.8 \times 10^{6} \mathrm{~km}^{2}$, followed by Argentina (16\%), Peru (7\%), Colombia (6\%), Bolivia (6\%), Venezuela (5\%) and Chile (4.2\%). Thus, combined contributions of Brazil and Argentina for the periods 2016-2020, 2021-2035 and 2036-2050 account for 87.5, 93.0 and 91.7\%, respectively, of the total C-offset for SA. The impact of each LCA activity has been calculated on the basis of the weighted average considering the entire period of 2015-2050 where the C-Offset is 8.24 Pg C (Fig. 1). The synergism between agricultural best management practices guides the scenarios and show that the strategy is to optimize the interactions

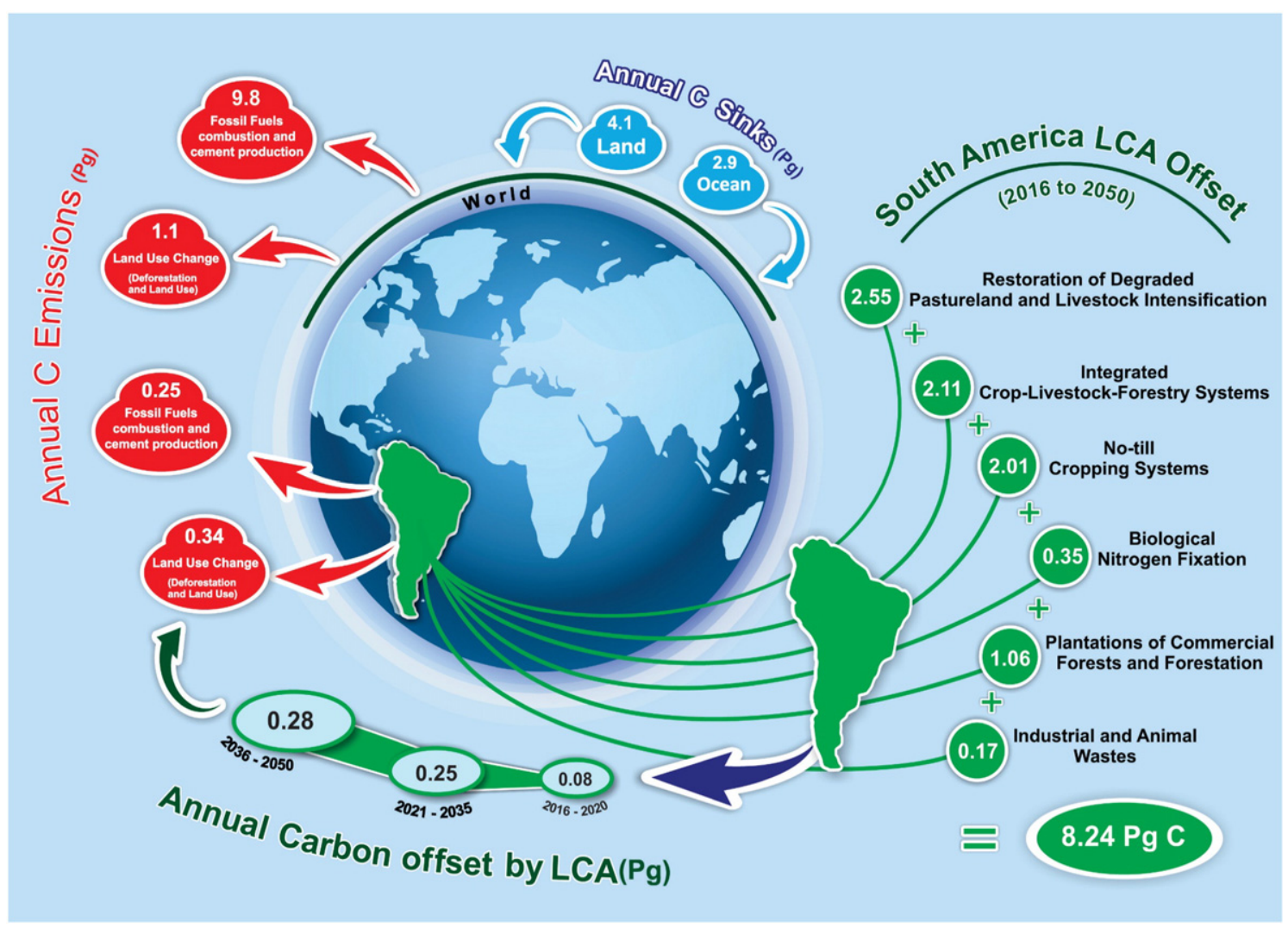

Fig. 1. Global carbon emissions and sinks, and South America C-offset by Low Carbon Agriculture ( $1 \mathrm{Pg} C=1$ billion ton of $\mathrm{C})$. 
Table 4

Increase in food production (million ton = Mton) for the period 2016 to 2050 through adoption of Low-Carbon Agriculture (LCA) activities (RDPLi, ICLFS, and NTcs) in South America based on soybean, cereal and meat production area (million ha $=$ Mha).

\begin{tabular}{|c|c|c|c|c|}
\hline \multirow[t]{2}{*}{ Agricultural product } & \multicolumn{3}{|c|}{ LCA activity $^{\mathrm{a}}$} & \multirow{2}{*}{$\begin{array}{l}\text { Total food } \\
\text { production }\end{array}$} \\
\hline & RDPLi & ICLFS & $\overline{N T c s}$ & \\
\hline \multicolumn{5}{|l|}{ Expansion area, $\mathrm{M}$ ha } \\
\hline Soybean & 9.4 & 13.3 & 54.3 & - \\
\hline Maize & 9.4 & 20.0 & 23.3 & - \\
\hline Wheat & 9.4 & 6.7 & 15.5 & - \\
\hline Meat (cattle) & 65.8 & 26.5 & - & - \\
\hline \multicolumn{5}{|l|}{ Food Production ${ }^{\mathrm{b}}$, Mton } \\
\hline Soybean & 29.7 & 42.0 & 171.6 & 243.3 \\
\hline Maize & 50.9 & 108.4 & 126.3 & 285.6 \\
\hline Wheat & 25.6 & 18.2 & 42.2 & 86.0 \\
\hline Meat (cattle) & 39.5 & 16.0 & - & 55.5 \\
\hline Soybean and cereal production gain & 106.2 & 168.6 & 340.1 & 614.9 \\
\hline Meat production gain & 39.5 & 16.0 & - & 55.5 \\
\hline Annual gain in crop production & - & - & - & 17.6 \\
\hline Annual gain in meat production & - & - & - & 2.2 \\
\hline
\end{tabular}

a LCA activity: RDPLi = Restoration of Degraded Pastureland and Livestock intensification; ICLFS = Integrated Crop-Livestock-Forestry Systems; NTcs = No-till cropping systems.

b Food production was obtained by multiplying yield production ha ${ }^{-1}$ by the expansion area in Mha. Average yields for estimation: Soybean $=3.16$ ton ha $^{-1}$; Maize $=5.42$ ton $\mathrm{ha}^{-1} ;$ Wheat $=2.72$ ton $\mathrm{ha}^{-1}$.

between practices. The NT cropping systems applied only to annual crops responded with a limited C offset of $24.4 \%$, but when the base line is integrated with the crop-livestock-forestry components to constitute integrated crop-livestock-forestry-systems, this contribution increases to $50 \%$. The main point of the debatable issue concerning NT systems is not to discuss this matter in isolation of the agricultural best management practices. Thus, the strategy is the combination of best management practices tools resulting in a better performance. The data presented herein show an overlap between the benefits of LCA in the total area. The net LU and LUC expansion is based mainly in four LCA components: restoration of degraded pastureland and livestock intensification, integrated crop-livestock-forestry-systems, NT cropping systems and plantations of commercial forest and forestation. The biological $\mathrm{N}$ fixation and industrial and animal waste components are included in the land expansion for time that these two components are associated with the crop or soil management in the LCA components mentioned previously. The total land expansion predicted by LCA in SA was 241 Mha because the activities such as industrial and animal waste and biological $\mathrm{N}$ fixation area comprise part of the activities of integrated crop-livestock-forestry-systems or NT cropping systems, and restoration of degraded pastureland and livestock intensification are in cleared area and part of the land surface maybe either abandoned or has low productivity.

\subsection{Ecosystems carbon pay-back time and food production increase by LCA strategies}

In the first scenario the ecosystems $C$ pay-back time calculated on the basis of LCA activities for the forest biomass burning and soil oxidation is $~ 188$ years and the mitigation potential is $7.5 \%$ of the world LU emissions. In the meantime, the effort for this period is far from accomplishing the ecosystems $\mathrm{C}$ pay-back time due to the finite $\mathrm{C}$ accumulation in soils and limiting $C$ storage to no longer than 50 to 70 years (Adenle et al., 2015; Lal, 2015; Sommer and Bossio, 2014). The goal of restoring degraded pasture and livestock intensification contributed $41.8 \%$ of the mitigation and the effort of the intensification based on carrying capacity adjusting for better forage species could be the driving force to enhance this strategy.

In the second scenario the ecosystems $C$ pay-back time is reduced to 63 years and intensification of LCA activities promoted $22.3 \%$ of the world LU emissions because of the intensification process compared to the first period and is also compatible with soil C sink capacity.

In the third scenario the pay-back time in this period is decreased to 56 years, and is a feasible $C$ accumulation interval that can lead to an extra $\mathrm{C}$ storage through adoption of those practices which create a positive soil carbon budget and also enhance the mean residence time of the carbon. In addition to the magnitude of input of biomass carbon, its quality and composition are also important to SOC sequestration. The improvement of synergistic actions between agricultural best management practices can consolidate a better performance of the agricultural activities achieving $\sim 25.2 \%$ of the mitigation of the world emissions.

The estimate of food production (Table 4) was based on the expansion of the area under oil crop (soybean) and cereals (maize and wheat). The adoption of LCA strategies can increase 615 Mton of cereals and edible oils and 55 Mton of meat. Proportioning for restoration of degraded pastureland and livestock intensification, integrated crop-livestock-forestry-systems and NT cropping systems and the meat production was done similarly and following the procedure described. The contribution of NT cropping systems was 55.3\% and followed by integrated crop-livestock-forestry-systems (27.4\%) and restoring degraded pasture and livestock intensification (17.3\%) ratifying that environmental conservation with the adoption of an agricultural system that reduces soil losses and preserving it for a long period is a reliable strategy. Although it has the highest mitigation capacity compared to Restoring degraded pasture and livestock intensification and integrated crop-livestock-forestry-systems stands out in greater grain production.

\subsection{Soil organic carbon sequestration in a changing climate}

The projected climate change may alter SOC sequestration rates and limit the mitigation potential of LCA activities but a detailed analysis of the consequences is beyond the scope of this study. Climate change involving: (i) increases in atmospheric $\mathrm{CO}_{2}$ concentrations; (ii) increases in air temperatures; (iii) significant and/or abrupt changes in daily, seasonal, and inter-annual temperature; (iv) changes in the wet/dry cycles; (v) increase in frequency of intensive rainfall and/or heavy storms; (vi) increase in extended periods of drought; (vii) increase in extreme frost; (viii) increase in heat waves; and (ix) increasee in fire frequency, which may all affect SOC sequestration (Qafoku, 2015). Response of SOC to climate change can be complex, along with numerous uncertainties and unresolved issues. Among them are: (i) accelerated weathering of soil minerals and along with increase in SOC fluxes in and out of soils; (ii) increased use of soil/geo-engineering methods used to increase SOC sequestration; (iii) increased SOC protection, transformation and mineralization; and (iv) increased sensitivity of SOC to temperature (Qafoku, 2015).

There exists a vast uncertainty in responses of belowground $C$ flux estimates to climate change induced alterations in soil $C$ inputs and heterotrophic respiration (Le Quéré et al., 2014 and 2015). SOC input and output fluxes depend on environmental variables which may change with change in the future climate, but the sensitivity of these fluxes is not adequately known (Giorgi, 2006). For example, the primary soil C input of net primary production (NPP) generally increases with increase in temperature, moisture, and $\mathrm{CO}_{2}$ up to some maximum, and which increases inputs of $C$ into soil (Todd-Brown et al., 2014). However, increase in NPP due to climate change and any attendant increase in SOC sequestration are not known. There is a large uncertaintly in possible increase in loss of $\mathrm{C}$ added through decomposition, erosion or leaching. Further, the primary pathway of the loss of SOC via heterotrophic respiration is also sensitive to climate change. In general, the heterotrophic respiration increases with increase in temperature (Davidson and Janssens, 2006) and moisture regimes in well-drained soils (Cook and Orchard, 2008). While the decomposition of SOC may increase with increase in temperature (Bond-Lamberty and Thomson, 2010), recent studies have postulated that this may be a temporary 
effect, potentially mitigating the expected SOC losses due to climate change (Kirschbaum, 1995). Specifically, microbial heterotrophic activity may adapt to sustained temperature increase by a decrease in heterotrophic soil respiration rate per unit microbial biomass (Bradford et al., 2008). Nevertheless, many studies have hypothesized that rising temperatures may increase SOC losses through decrease in the soil turnover times. However, aggregate formation and mineral-organic interactions may enhance SOC sequestration and stabilize SOC (Dungait et al., 2012), limiting the response to increased temperature.

Many Earth system models (ESMs) have predicted increases in SOC depending on sustained increases in NPP with global change primarily driven by increasing $\mathrm{CO}_{2}$ (Todd-Brown et al., 2014). However, most ESMs omitted potential constraints on SOC sequestration and storage, such as the priming effects, nutrient availability, mineral surface stabilization, and aggregate formation. However, not accounted for are microbial acclimation to increasing temperatures (Chen and Tian, 2005), and $\mathrm{CO}_{2}$-induced changes in the microbial community composition (Carney et al., 2007). For example, microbial models predict stronger SOC responses to climate change compared to the ESMs which do not explicitly include microbial biomass dynamics into the $\mathrm{C}$ cycle model formulations (Hararuk et al., 2015). The primary areas of empirical uncertainty that generate low confidence in feedback projections of SOC to climate change are: (i) the paucity of direct observations of warming effects on SOC stocks; (ii) the potential for organism responses to warming to alter short-term biogeochemical responses; and (iii) the dramatically changing ideas about how SOC formation and stabilization are regulated (Bradford et al., 2016). The major modelling uncertainty is associated with representing common and outdated ideas about SOC turnover in the soil sub-models of the ESMs. Thus, representing an advanced understanding of SOC stabilization in models would be the first step to build confidence in projections of SOC feedbacks to climate change (Tang and Riley, 2015). Specifically, important advances in understanding the temperature response of the processes that control substrate availability, depolymerization, microbial efficiency, and enzyme production are needed to predict the fate of SOC stocks in a warmer world (Conant et al., 2011).

\section{Conclusions}

The adoption of agricultural systems in South America based on Low-Carbon Agriculture strategies can alter the growing trend of Land Use and Land Use Change emissions. It can offset the global annual emissions by $7.5 \%$ for 2016 to $2020,22.3 \%$ for 2021 to 2035 and $25.2 \%$ for 2036 to 2050, and mitigate $8.24 \mathrm{Pg} \mathrm{C}$ for the 2016 to 2050 period. The contribution of NT cropping system to mitigate global climate change, based on weighted average for Low-Carbon Agriculture strategies for the entire period, is as much as $24.3 \%$. The impact of NT is especially effective when combined with other agricultural best management practices such as restoring degraded pasture and livestock intensification (31.0\%) and integrated crop-livestock-forestry system (25.6\%). Thus, the contribution of those three activities are equivalent to $80.9 \%$ of the global emissions by Land Use and Land Use Change. In this study the ecosystem $C$ pay-back time was feasible only for the second ( 63 years) and the third scenario period ( 56 years) considering that $\mathrm{C}$ accumulation in soils is limited to 70 years. The adoption of Low-Carbon Agriculture strategies can also increase food production for the entire period (2016 to 2050) by 615 Mton in the expanded land area under best management practices and 55 Mton of meat. The expansion of NT cropping system can produce $55.3 \%$ of the cereal and oil crops while the restoration of degraded pasture and livestock intensification account for $71.2 \%$, and integrated crop-livestock-forestry system contributes $28.8 \%$ of meat production. These results indicate that combined actions in agricultural management systems can result in synergistic responses that can be the basis to make agriculture an important part of the solution of the global climate change and advance food security.

\section{Authors contribution}

Dr. J.C.M. Sá develop the framework, methodology, coefficients, calculations, interpretations and all definitions; Dr. R. Lal conceptualized the project, developed the framework and the methodology of $C$ budget, interpretations and edited the manuscript; C.C. Cerri discussed the global C scenario; K. Lorenz discussed the global C scenario and high contribution in the discussion section and revision; Dra. M. Hungria discussed the interpretations of biological $\mathrm{N}$ fixation and the coefficients for calculations; Dr. P.C.F. Carvalho elaborated the framework for integrated livestock and forest systems and degraded areas, and the coefficients. All authors had total dedication in the writing and revision of the manuscript.

\section{Acknowledgements}

The first author was supported by CAPES Fellowship (Grant \# 006792/2014-06) and the research was partially funded by CNPq (Grant \# 482292/2012-1), and worked in collaboration with Carbon Management and Sequestration Center from The Ohio State University.

\section{References}

AAPRESID, 2015. Argentina. http://www.aapresid.org.ar/superficie/.

Adenle, A., Azadi, H., Arbiol, J., 2015. Global assessment of technological innovation for climate change adaptation and mitigation in developing world. J. Environ. Manag. 161, 261-275.

Agriculture Ministry of Brazil - Soybean and grain production, o. http://www.agricultura. gov.br/comunicacao/noticias/2015/03/producao-estimada-de-graos-e-de-198milhoes-de-toneladas (accessed in June of 2015).

Allen, V.G., Batello, C., Berretta, E.J., Hodgson, J., Kothmann, M., McIvor, X., Li, J., Milne, J. Morris, C., Peeters, A., Sanderson, M., 2010. An international terminology for grazing lands and grazing animals. Grass Forage Sci. 66, 2-28.

Alvarez, C., Alvarez, C.R., Costantini, A., Basanta, M., 2014. Carbon and nitrogen sequestration in soils under different management in the semi-arid Pampa (Argentina). Soil Tillage Res. 142, 25-31.

Alvarez, R., 2005. Carbon stocks in Pampean soils: a simple regression model for estimation of carbon storage under nondegraded scenarios. Commun. Soil Sci. Plant Anal. 36, 1583-1589.

Antle, J.M., Ogle, S.M., 2012. Influence of soil C, $\mathrm{N}_{2} \mathrm{O}$ and fuel use on GHG mitigation with no-till adoption. Clim. Chang. 111, 609-625.

Bayer, C., Martin-Neto, L., Mielniczuk, J., Pavinato, A., Dieckow, J., 2006. Carbon sequestration in two Brazilian Cerrado soils under no-till. Soil Tillage Res. 86 237-245.

Blanchart, E., Bernoux, M., Sarda, X., Siqueira Neto, M., Cerri, C.C., Piccolo, M., Douzet, J.M., Scopel, E., Feller, C., 2007. Effect of direct seeding mulch-based systems on soil carbon storage and macrofauna in central brazil. Agric. Conspec. Sci. 72, 81-87.

Boddey, R.M., Jantalia, C.P., Conceicao, P.C., Zanatta, J.A., Bayer, C., Mielniczuk, J., Dieckow, J., dos Santos, H.P., Denardin, J.E., Aita, C., Giacomini, S.J., Alves, B.J.R., Urquiaga, S. 2010. Carbon accumulation at depth in Ferralsols under zero-till subtropical agriculture. Glob. Chang. Biol. 16, 784-795.

Bond-Lamberty, B., Thomson, A., 2010. Temperature-associated increases in the global soil respiration record. Nature 464, 579-582.

Bradford, M.A., Davies, C.A., Frey, S.D., Maddox, T.R., Melillo, J.M., Mohan, J.E., Reynolds, J.F Treseder, K.K., Wallenstein, M.D., 2008. Thermal adaptation of soil microbial respiration to elevated temperature. Ecol. Lett. 11, 1316-1327.

Bradford, M.A., Wieder, W.R., Bonan, G.B., Fierer, N., Raymond, P.A., Crowther, T.W., 2016 Managing uncertainty in soil carbon feedbacks to climate change. Nat. Clim. Chang. 6, 751-758.

Brazilian Low-Carbon Agriculture Program, 2012. http://www.climateactionprogramme. org/news/brazils_low_carbon_agriculture_programme.

Brazilian participation on COP 21, d. http://www.wri.org/blog/2015/12/cop21surprise-brazilian-states-commit-restore-more-3-million-hectares-degradedland.

Brazilian National Federation of No-Tillage. http://www.febrapdp.org.br/. (Access in December of 2015).

Carney, K.M., Hungate, B.A., Drake, B.G., Megonigal, J.P., 2007. Altered soil microbial community at elevated $\mathrm{CO}_{2}$ leads to loss of soil carbon. P. Natl. Acad. Sci. USA 104 4990-4995.

Carter, S., Herold, M., Rufino, M.C., Neumann, K., Kooistra, L., Verchot, L., 2015. Mitigation of agricultural emissions in the tropics: comparing forest land-sparing options at the national level. Biogeosciences 12, 4809-4825.

Carvalho, P.C.d.F., Batello, C., 2009. Access to land, livestock production and ecosystem conservation in the Brazilian Campos biome: The natural grasslands dilema. Livest Sci. $120,158-162$. 
Castelhano, M.J., Mueller, K.E., Olk, D.C., Sawyer, J.E., Six, J., 2015. Integrating plant litter quality, soil organic matter stabilization and the carbon saturation concept. Glob. Chang. Biol. 21, 3200-3209.

Chen, H., Tian, H.Q., 2005. Does a general temperature-dependent Q10 model of soil respiration exist at biome and global scale? J. Integr. Plant Biol. 47, 1288-1302.

Conant, R.T., Ryan, R.G., Ågren, G.I., Birge, H.E., Davidson, E.A., Eliasson, P.E., Evans S.E., Frey, S.D., Giardina, C.P., Hopkins, F.M., Hyvönen, R., Kirschbaum, M.U.F. Lavallee, J.M., Leifeld, J., Parton, W.J., Steinweg, J.M., Wallenstein, M.D. Wetterstedt, J.Å.M., Bradford, M.A., 2011. Temperature and soil organic matter decomposition rates - synthesis of current knowledge and a way forward. Glob. Chang. Biol. 17, 3392-3404.

Cook, F.J., Orchard, V.A., 2008. Relationships between soil respiration and soil moisture. Soil Biol. Biochem. 40, 1013-1018.

Corbeels, M., Marchão, R.L., Siqueira Neto, M., Ferreira, E.G., Madari, B.E., Scopel, E., Brito O.R., 2016. Evidence of limited carbon sequestration in soils under no-tillage systems in the Cerrado of Brazil. Nature Comm. Sci. Rep. 6:21450. http://dx.doi.org/10.1038/ srep21450.

Darela Filho, J.P., Lapola, D.M., Torres, R.R., Lemos, M.C., 2016. Socio-climatic hotspots in Brazil: how do changes driven by the new set of IPCC climatic projections affect their relevance for policy? Clim. Chang. 136, 413-425.

Davidson, E.A., Janssens, I.A., 2006. Temperature sensitivity of soil carbon decomposition and feedbacks to climate change. Nature 440, 165-173.

Derpersch, R., Franzluebbers, A.J., Duiker, S.W., Reicosky, D.C., Koeller, K., Friedrich, T. Sturny, W.G., Sá, J.C.M., Weiss, K., 2014. Why do we need to standardize no-tillage research? Soil Tillage Res. 137, 16-22.

Diaz-Zorita, M., Duarte, G.A., Grove, J.H., 2002. A Review of no-till system and soil management for sustainable crop production in the subhumid and semiarid Pampa Argentina. Soil Tillage Res. 65, 1-18.

Diekow, J., Mielniczuk, J., Knicker, H., Bayer, C., Dick, D.P., Kögel-Knabner, I., 2005. Soil $\mathrm{C}$ and $\mathrm{N}$ stocks as affected by cropping systems and nitrogen fertilisation in a southern Brazil Acrisol managed under no-tillage for 17 years. Soil Tillage Res. 81, 87-95.

Duinker, P.N., Greig, L.A., 2007. Scenario analysis in environmental impact assessment: improving explorations of the future. Environ. Impact Assess. Rev. 27, 206-219.

Dungait, J.A.J., Hopkins, D.W., Gregory, A.S., Whitmore, A.P., 2012. Soil organic matter turnover is governed by accessibility not recalcitrance. Glob. Chang. Biol. 18, $1781-1796$.

FAO, 2014. Principles of no-till. http://www.fao.org/ag/Ca/6c.html.

FAOSTAT (http://faostat.fao.org/site/377/DesktopDefault.aspx?PageID=377\#ancor), (accessed in Nov 03, 2015)

Food and Agriculture Organization of the United Nations - FAO. FAOSTAT (http://faostat fao.org/site/377/DesktopDefault.aspx?PageID=377\#ancor), (accessed in Jun 03, 2015).

Food and Agriculture http://www.earth-policy.org/data_center/C24 (accessed in Jan. 2016).

Gebara, M.F., Thuault, A., 2010. GHG Mitigation in Brazil's Land Use Sector: An Introduction to the Current National Policy Landscape. Online version: http://www.ccrasa. com/library_1/14039\%20-\%20GHG\%20Mitigation\%20in\%20Brazils\%20Land\%20Use\% 20Sector\%20-\%20An\%20Introduction\%20to\%20the\%20Current\%20National\%20Policy\% 20Landscape.pdf.

Gibbs, H.K., Johnston, M., Foley, J.A., Holloway, T., Monfreda, C., Ramankutty, N., Zaks D., 2008. Carbon payback times for crop-based biofuel expansion in the tropics: the effects of changing yield and technology. Environ. Res. Lett. 3, 034001 (10pp) (2008).

Gibbs, H.K., Salmon, J.M., 2015. Mapping the world's degraded lands. Appl. Geogr. 57 $12-21$.

Gil, J., Siebold, M., Berger, T., 2015. Adoption and development of integrated croplivestock-forestry systems in Mato Grosso, Brazil. Agric. Ecosyst. Environ. 199, 394-406.

Giorgi, F., 2006. Climate change hot-spots. Geophys. Res. Lett. 33, L08707. http://dx.doi. org/10.1029/2006GL025734.

Gloor, M., Gatti, L., Brienen, R., Feldpausch, T.R., Phillips, O.L., Miller, J., Houghton, R.A., 2012. The carbon balance of South America: a review of the status, decadal trends and main determinants. Biogeosciences 9, 5407-5430.

Gouvello, C., Soares-Filho, B.S., Nassar, A., Schaeffer, R., Alves, F.J., Alves, J.W.S., 2010. Brazil Low-carbon Country Case Study. The International Bank for Reconstruction and Development/The World Bank. http://siteresources.worldbank.org/BRAZILEXTN/ Resources/Brazil_LowcarbonStudy.pdf.

Groppo, J.D., Lins, S.R.M., Camargo, P.B., Assad, E.D., Pinto, H.S., Martins, S.C., Pavão, E., 2015. Changes in soil carbon, nitrogen, and phosphorus due to land-use changes in Brazil. Biogeosciences 12, 4765-4780.

Gusso, A., Formaggio, A.R., Rizzill, R., Adami, M., Rudorff, B.F.T., 2012. Soybean crop area estimation by MODIS/EVI data. Remote Sens. 47, 425-435.

Hararuk, O., Smith, M.J., Luo, Y., 2015. Microbial models with data-driven parameters predict stronger soil carbon responses to climate change. Glob. Chang. Biol. 21, 2439-2453.

Hernanz, J.L., Sanchez-Girón, V., Navarrete, L., 2009. Soil carbon sequestration and stratification in a cereal/leguminous crop rotation with three tillage systems in semiarid conditions. Agric. Ecosyst. Environ. 133, 114-122.

Hobbs, P.R., Sayre, K., Gupta, R., 2008. The role of conservation agriculture in sustainable agriculture. Philos. Trans. R. Soc. B 363, 543-555.

Houghton, R.A., 2014. Contemporary C cycle. Treatize on Geochemistry, pp. 399-435.

Hungria, M., Franchini, J.C., Campo, R.J., Crispino, C.C., Moraes, J.Z., Sibaldelli, R.N., Arihara, J., 2006. Nitrogen nutrition of soybean in Brazil: Contributions of biological $\mathrm{N}_{2}$ fixation and $\mathrm{N}$ fertilizer to grain yield. Can. J. Plant Sci. 927-939.
Kang, M. A brief analysis of low-carbon agriculture development pattern. Business and Management Research, v. 2: 96-99 (2013).

Kassam, A. H., Friedrich, T., Derpsch, R., \& Kienzle, J. Worldwide of Conservation Agriculture. 6th World Congress of Conservation Agriculture, 22-27 June 2014, Winnipeg, Canada http://www.ctic.org/WCCA/ (2015).

Kirkegaard, J.A., Conyers, M.K., Hunt, J.R., Kirkby, C.A., Watt, M., Rebetzke, G.J., 2014. Sense and nonsense in conservation agriculture: principles, pragmatism and productivity in Australian mixed farming systems. Agric. Ecosyst. Environ. 187, 133-145.

Kirschbaum, M.U.F., 1995. The temperature dependence of soil organic matter decomposition, and the effect of global warming on soil organic C storage. Soil Biol. Biochem. 27, 753-760.

Lal, R., 2010. Beyond Copenhagen: mitigating climate change and achieving food security through soil carbon sequestration. Glob. Food Sec. 2, 169-177.

Lal, R., 2015. Sequestering carbon and increasing productivity by conservation agriculture. J. Soil Water Conserv. 70, 55-62.

Lal, R., 2014. Societal value of soil carbon. J. Soil Water Conserv. 6, 186-192.

Lal, R., 2004. Soil carbon sequestration impacts on global climate change and food security. Science 304, 1623-1627.

Lam, S.K., Chen, D., Mosier, A.R., Roush, R., 2013. The potential for carbon sequestration in Australian agricultural soils is technically and economically limited. Sci. Rep. 3, 2179-2184.

Le Quéré, C., Moriarty, R., Andrew, R.M., Peters, G.P., Ciais, P., Friedlingstein, P., .. Boden, T.A., 2014. Global carbon budget 2014. Earth Syst. Sci. Data Discuss. 7 , 521-610.

Le Quéré, C., Moriarty, R., Andrew, R.M., Canadel, J.G., ... Zeng, N., 2015. Global carbon budget 2015. Earth Syst. Sci. Data 7, 349-396.

Magalhães, M. M., Lunas Lima, D. A. L. Low-Carbon Agriculture in Brazil: The Environmental and Trade Impact of Current Farm Policies. International Centre for Trade and Sustainable Development (ICTSD), Issue paper 54, 28p. (2014).

Miranda, E., Carmo, J., Couto, E., Camargo, P. Long-term changes in soil carbon stocks in the Brazilian cerrado under commercial soybean. Land Degrad. Dev. Online, DOI: 10.1002/ldr.2473 (2016).

Moraes, A., de Faccio Carvalho, P.C., Anghinoni, I., Lustosa, S.B.C., de Andrade, S.E.V.G., Kunrath, T.R., 2014. Integrated crop-livestock systems in the Brazilian subtropics. Eur. J. Agron. 57, 4-9.

National Brazilian Grain Production Survey, 2015. http://www.agricultura.gov.br/ comunicacao/noticias/2015/09/safra-brasileira-20142015-fecha-com-recorde-de209-milhoes-de-toneladas-de-graos

Neufeldt, H., Kissinger, G., Alcamo, J., 2015. No-till agriculture and climate change mitigation. Nat. Clim. Chang. 5, 488-489.

Neufeldt, H., Adhya, T. K., Coulibaly, J. Y., Kissinger, G. \& Pan, G. in The Emissions Gap Report 2013 Ch.4 (United Nations Environment Programme, 2013).

Ormeño-Orrillo, E., Hungria, M., Martínez-Romero, E., 2013. Dinitrogen-fixing prokaryotes. In: Rosemberg, E., DE Long, E.F., Lory, S., Stackebrandt, E., Thompson, F. (Eds.), Chapter 11. The Prokaryotes - Prokaryotic Physiology and Biochemistry. SpringerVerlag, Berlin Heidelberg, pp. 427-451.

Qafoku, N.P., 2015. Climate-change effects on soils: accelerated weathering, soil carbon, and elemental cycling. Adv. Agron. 131, 111-172.

Pittelkow, C.M., Liang, X., Linquist, B.A., Van Groenigen, K.J., Lee, J., Lundy, M.E., ... van Kessel, C., 2014. Productivity limits and potentials of the principles of conservation agriculture. Nature 517, 365-370.

Powlson, D.S., Stirling, C.M., Thierfelder, C., White, R.P., Jat, M.L., 2016. Does conservation agriculture deliver climate change mitigation through soil carbon sequestration in tropical agro-ecosystems? Agriculture. Ecol. Environ. 220, 164-174.

Powlson, D.S., Stirling, C.M., Jat, M.L., Gerard, B.G., Palm, C.A., Sanchez, P.A., Cassman, K.G., 2014. Limited potential of no-till agriculture for climate change mitigation. Nat. Clim. Chang. 4, 678-683.

Robertson, G.P., Grace, P.R., 2004. Greenhouse gas fluxes in tropical and temperate agriculture: the need for a full-cost accounting of global warming potentials. Environ. Dev. Sustain. 6, 51-63.

Sá, J.C.dM., Séguy, L., Gozé, E., Bouzinac, S., Husson, O., Boulakia, S., Tivet, F., Forest, F., Santos, J.B., 2006. Carbon sequestration rates in no-tillage soils under intensive cropping systems in tropical agro-ecozones. Edafologia 13, 139-150.

Sá, J.C.M., Séguy, L., Tivet, F., Lal, R., Bouzinac, S., Borszowskei, P.R., ... Rosa, J., 2015. Carbon depletion by plowing and its restoration by no-till cropping systems in Oxisols of subtropical and tropical Agro-ecoregions in Brazil. Land Degrad. Dev. 26, 531-543.

Sá, J.C.M., Tivet, F., Lal, R., Briedis, C., Hartman, D.C., dos Santos, J.Z., dos Santos, J.B., 2014. Long-term tillage systems impacts on soil C dynamics, soil resilience and agronomic productivity of a Brazilian Oxisol. Soil Tillage Res. 136, 38-50.

Sá, J.C.M., Bürkner dos Santos, J., Lal, R., de Moraes, A., Tivet, F., Sá, M.F.M., ... Farias, A., 2013. Soil-specific inventories of landscape $C$ and $N$ stocks under no-till and native vegetation to estimate C offset in a subtropical ecosystem. Soil Sci. Soc. Am. J. 77, 2094-2110.

Soares-Filho, B., Lima, L., Bowman, M., Viana, L., 2012. Inter American Development Bank Environmental Safeguards Unit. (VPS/ESG) Technical notes No. IDB-TN-385, 40p. http://publications.iadb.org/handle/11319/5407?locale-attribute $=e n$.

Sommer, R., Bossio, D., 2014. Dynamics and climate change mitigation potential of soil organic carbon sequestration. J. Environ. Manag. 144, 83-87.

Tang, J., Riley, W.J., 2015. Weaker soil carbon-climate feedbacks resulting from microbial and abiotic interactions. Nat Clim. Chang. 5, 56-60.

The three principles of conservation agriculture, 2014. http://www.fao.org/assets/ infographics/CA-principles-Infographic.pdf.

Tilman, D., Clark, M., 2014. Global diets link environmental sustainability and human health. Nature $515,518-524$ 
Tilman, D., Cassman, K.G., Matson, P.A., Naylor, R., Polasky, S., 2002. Agricultural sustainability and intensive production practices. Nature 418:671-677. http://dx.doi.org/ 10.1038/nature01014.

Todd-Brown, K.E.O., Randerson, J.T., Hopkins, F., Arora, V., Hajima, T., Jones, C. Shevliakova, E., Tjiputra, J., Volodin, E., Wu, T., Zhang, Q., Allison, S.D., 2014. Changes in soil organic carbon storage predicted by earth system models during the 21st century. Biogeosciences 11, 2341-2356.

UN, 2014. Universal Declaration of Human Rights. http://www.un.org/es/documents/ udhr/.

VandenBygaart, A.J., 2016. The myth that no-till can mitigate global climate change. Agric. Ecosyst. Environ. 216, 98-99.
Zhu, C., Lu, D., Victoria, D., Dutra, L.V., 2016. Mapping fractional cropland distribution in Mato Grosso, Brazil using time series MODIS enhanced vegetation index and landsat thematic mapper data. Remote Sens. 8:22. http://dx.doi.org/10.3390/rs8010022.

\section{Further Reading}

Brazilian deforestation survey, 2015. http://rainforests.mongabay.com/amazon/ deforestation_calculations.html. 